\title{
PIJAT BATUK PILEK PADA BAYI DI KELURAHAN MAHARANI KECAMATAN RUMBAI PESISIR
}

\author{
Riza Febrianti ${ }^{1)}$ Juli Selvi Yanti ${ }^{2)}$ \\ STIKes Hang Tuah Pekanbaru ${ }^{1)}$ \\ Email : rizafebrianti77@yahoo.com
}

\begin{abstract}
Massage is a form of touch therapy that serves as an important treatment technique. Even according to modern research, regular baby massage can help the baby's physical and emotional growth and development, in addition to maintaining his health. What is certain is that the benefits of baby massage are not only felt by the little one, but also by the mother.

Outreach and stunting training activities were held on November 28, 2019, as many as 31 people in Maharani Village, Rumbai Pesisir District, Pekanbaru City. The results of the activity are increased knowledge and understanding of mothers about the benefits of cold cough massage for their babies and mothers can practice how to massage cold coughs on their babies. This can be seen from the ability of mothers to answer questions raised by the presenters and the willingness of mothers to practice massage the baby
\end{abstract}

Keywords: Cough and Cold Massage

\begin{abstract}
ABSTRAK
Pijat merupakan salah satu bentuk dari terapi sentuh yang berfungsi sebagai salah satu teknik pengobatan penting. Bahkan menurut penelitian modern, pijat bayi secara rutin dapat membantu tumbuh kembang fisik dan emosi bayi, disamping mempertahankan kesehatannya. Yang pasti manfaat pijat bayi tidak hanya dirasakan oleh si kecil saja, tapi demikian juga oleh ibu.

Kegiatan penyuluhan dan pelatihan Stunting (Kerdil) telah dilaksanakan pada tanggal 28 November 2019 sebanyak 31 orang di Kelurahan Maharani Kecamatan Rumbai Pesisir Kota Pekanbaru. Hasil dari kegiatan adalah Meningkatnya pengetahuan dan pemahaman ibu-ibu tentang manfaat pijat batuk pilek pada bayinya dan Ibu dapat mempraktikan cara pijat batuk pilek pada bayinya.Hal ini dilihat dari kemampuan ibu dalam menjawab pertanyaan yang diajukan oleh pemateri dan kesedian ibu untuk dilakukan praktik pijat kepada bayinya
\end{abstract}

Kata Kunci : Pijat Batuk Pilek 


\section{PENDAHULUAN}

Pijat bayi biasa disebut dengan stimulus touch. Pijat bayi dapat diartikan sebagai sentuhan komunikasi yang nyaman antara ibu dan bayi. Pijat bayi sudah dikenal sejak berabad-abad yang lalu, pada berbagai bangsa dan kebudayaan, dengan berbagai bentuk terapi dan tujuan. Pijat bayi merupakan pengungkapan rasa kasih sayang antara orang tua dengan anak lewat sentuhan kulit yang berdampak luar biasa (Maharani, 2009).

Pijat merupakan salah satu bentuk dari terapi sentuh yang berfungsi sebagai salah satu teknik pengobatan penting. Bahkan menurut penelitian modern, pijat bayi secara rutin dapat membantu tumbuh kembang fisik dan emosi bayi, disamping mempertahankan kesehatannya. Yang pasti manfaat pijat bayi tidak hanya dirasakan oleh si kecil saja, tapi demikian juga oleh ibu.

Batuk adalah respon alami dari tubuh sebagai sistem pengetahuan untuk mengeluarkan zat dan partikel dari dalam saluran pernapasan,serta mencegah benda asing masuk ke saluran napas bawah.

Pilek adalah infeksi ringan pada hidung, saluran sinus, tenggorokan, dan saluran pernapasan bagian atas akibat serangan virus. Pilek bisa dialami oleh siapa saja, mulai dari anak-anak hingga dewasa. Seorang yang sakit pilek akan mengalami gejala berupa: hidung terus menurus mengeluarkan ingus, sering bersin,sering batuk, pernapasan tidak lancer( hidung terasa tersumbat), tidak enak badan, suara serak.

\section{METODE PENERAPAN}

Metode pengabdian masyarakat ini dilaksanakan dalam bentuk Penyuluhan dan Metode demonstrasi atau praktik pijat batuk pilek dengan menerapkan langsung setelah diberikan penyuluhan

\section{HASIL DAN PEMBAHASAN}

\section{A. HASIL PELAKSANAAN}

Kegiatan penyuluhan dan pelatihan Stunting (Kerdil) telah dilaksanakan pada tanggal 28 November 2019 sebanyak 31 orang di Kelurahan Maharani Kecamatan Rumbai Pesisir Kota Pekanbaru. Berdasarkan wawancara, tanya jawab dan pengamatan langsung selama kegiatan pengabdian masyarakat ini memberikan hasil berikut:

1. Meningkatnya pengetahuan dan pemahaman ibu-ibu tentang manfaat pijat batuk pilek pada bayinya.

2. Ibu dapat mempraktikan cara pijat batuk pilek pada bayinya.Hal ini dilihat dari kemampuan ibu dalam menjawab pertanyaan yang diajukan oleh pemateri dan 
kesedian ibu untuk dilakukan praktik pijat kepada bayinya
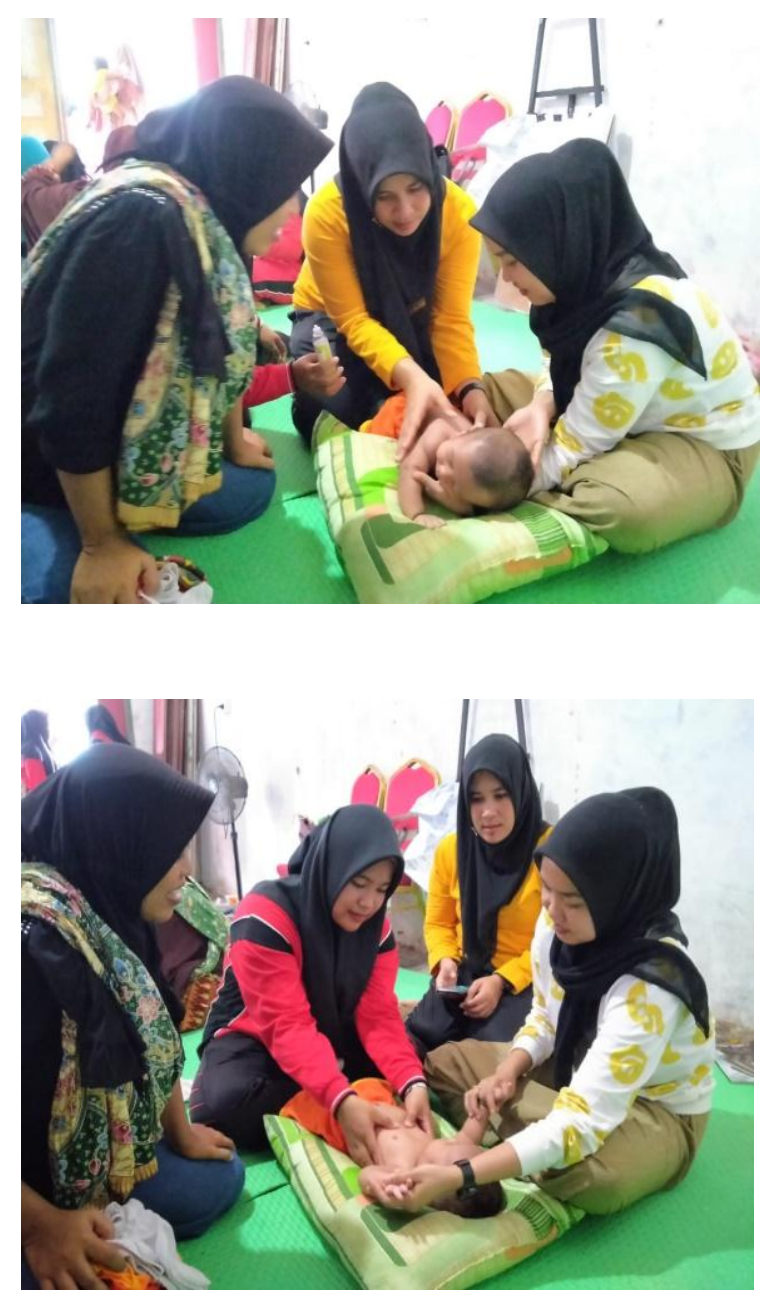

\section{B. Pembahasan}

Kegiatan penyuluhan dan praktik pijat batuk pilek pada bayi syang dilaksanakan di Kelurahan Maharani Kecamatan Rumbai Pesisir Kota Pekanbaru berjalan dengan baik dan sesuai rencana. Hal ini terbukti antusiasme para peserta saat mengikuti jalanya kegiatan. Para peserta penyuluhan benar-benar memperhatikan dan mendengarkan dengan baik penyuluhan dan praktik yang disampaikan.

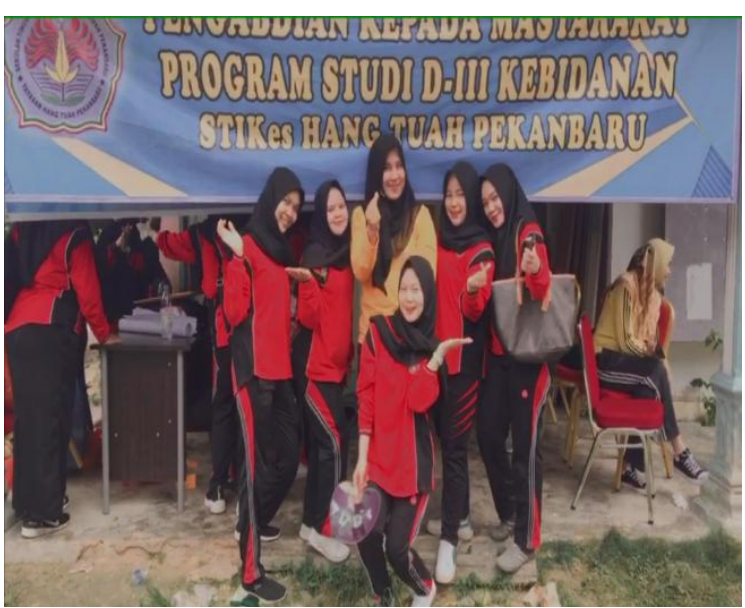

\section{KESIMPULAN}

Pijat merupakan salah satu bentuk dari terapi sentuh yang berfungsi sebagai salah satu teknik pengobatan penting. Bahkan menurut penelitian modern, pijat bayi secara rutin dapat membantu tumbuh kembang fisik dan emosi bayi, disamping mempertahankan kesehatanny. Yang pasti manfaat pijat bayi tidak hanya dirasakan oleh si kecil saja, tapi demikian juga oleh ibu.

Batuk adalah respon alami dari tubuh sebagai sistem pengetahuan untuk mengeluarkan zat dan partikel dari dalam saluran pernapasan,serta mencegah benda asing masuk ke saluran napas bawah.

Pilek adalah infeksi ringan pada hidung, saluran sinus, tenggorokan, dan saluran pernapasan bagian atas akibat serangan virus. Pilek bisa dialami oleh 
siapa saja, mulai dari anak-anak hingga dewasa. Seorang yang sakit pilek akan mengalami gejala berupa: hidung terus menurus mengeluarkan ingus, sering bersin,sering batuk, pernapasan tidak lancer( hidung terasa tersumbat), tidak enak badan, suara serak.

\section{DAFTAR PUSTAKA}

Roesli, U. 2001. Pedoman Pijat Bayi. Jakarta : Trubus Agriwidya International Beauty Spa.com Pijat medic pediatric dr jaya samsoedin 